\title{
BioCore Guide: A Tool for Interpreting the Core Concepts of Vision and Change for Biology Majors
}

\author{
Sara E. Brownell, ${ }^{*}$ Scott Freeman, ${ }^{\dagger}$ Mary Pat Wenderoth, ${ }^{\dagger}$ and Alison J. Crowe ${ }^{\dagger}$ \\ ${ }^{*}$ School of Life Sciences, Arizona State University, Tempe, AZ 85287; ${ }^{\dagger}$ Department of Biology, University of \\ Washington, Seattle, WA 98195
}

Submitted December 7, 2013; Revised February 23, 2014; Accepted February 24, 2014

Monitoring Editor: William B. Wood

\begin{abstract}
Vision and Change in Undergraduate Biology Education outlined five core concepts intended to guide undergraduate biology education: 1) evolution; 2) structure and function; 3) information flow, exchange, and storage; 4) pathways and transformations of energy and matter; and 5) systems. We have taken these general recommendations and created a Vision and Change BioCore Guide-a set of general principles and specific statements that expand upon the core concepts, creating a framework that biology departments can use to align with the goals of Vision and Change. We used a grassroots approach to generate the BioCore Guide, beginning with faculty ideas as the basis for an iterative process that incorporated feedback from more than 240 biologists and biology educators at a diverse range of academic institutions throughout the United States. The final validation step in this process demonstrated strong national consensus, with more than $90 \%$ of respondents agreeing with the importance and scientific accuracy of the statements. It is our hope that the BioCore Guide will serve as an agent of change for biology departments as we move toward transforming undergraduate biology education.
\end{abstract}

\begin{abstract}
The intent of the Vision and Change conversations and national conference was to move toward a consensus framework in the biology community that would be broadly adaptable, given the unique structures, capacities, and constraints of individual life sciences programs ... We pose these core concepts ... as a resource and starting point based on the collective experience and wisdom of a broad national community of biological scientists and educators.
\end{abstract}

Vision and Change (AAAS, 2011, p. 11)

Biology is without question the most diverse of the science, technology, engineering, and mathematics (STEM) disciplines. What began as an observational science has blossomed into a wide-ranging set of subdisciplines, each with

DOI: $10.1187 /$ cbe.13-12-0233

Address correspondence to: Sara E. Brownell (sebbers@gmail.com).

(C) 2014 S. E. Brownell et al. CBE-Life Sciences Education (C) 2014 The American Society for Cell Biology. This article is distributed by The American Society for Cell Biology under license from the author(s). It is available to the public under an AttributionNoncommercial-Share Alike 3.0 Unported Creative Commons License (http:/ / creativecommons.org/licenses/by-nc-sa/3.0).

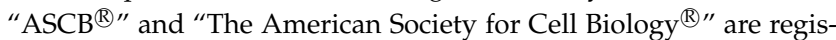
tered trademarks of The American Society for Cell Biology. its own set of key concepts, experimental techniques, and approaches to the study of life. The discipline is currently so segmented that biologists who work in particular subdisciplines attend separate scientific meetings, publish in specialty journals, and are sometimes housed in different departments.

The rapid expansion and increased diversity of the field has greatly expanded the scope and impact of biological discoveries but creates a challenge for instructors. The exponential rate of discovery in biology makes it difficult to decide what to teach in a 4-yr undergraduate curriculum. Given that we cannot teach everything, can we reach consensus about what is most important to teach?

\section{IDENTIFICATION OF CORE CONCEPTS IN UNDERGRADUATE BIOLOGY}

In an effort to consolidate the ever-expanding volume of biological knowledge to a more manageable set of ideas, several groups have outlined the "big ideas" in biology (Table 1). Some of these efforts are focused on biology as a whole, whereas others are targeted to specific subdisciplines. Collectively, this literature has laid a strong foundation for articulating the most important aspects of biology and several common "big ideas" have emerged. While these efforts have enhanced awareness, many lack large-scale validation, 
Table 1. Previous efforts to define the core ideas of biology

\begin{tabular}{|c|c|c|c|c|}
\hline Report/title & Date & Big ideas of biology & Audience & Citation \\
\hline BIO2010 & 2003 & $\begin{array}{l}\text { Eighteen one- to two-sentence concepts } \\
\text { for undergraduate biology curriculum }\end{array}$ & $\begin{array}{l}\text { General undergraduate } \\
\text { biology }\end{array}$ & NRC, 2003, pp. 32-33 \\
\hline $\begin{array}{l}\text { Biology Concept } \\
\text { Framework (BCF) }\end{array}$ & 2004 & $\begin{array}{l}\text { Hierarchical, cross-referenced concepts } \\
\text { related to genetics and molecular } \\
\text { biology }\end{array}$ & $\begin{array}{l}\text { Subdiscipline } \\
\text { undergraduate biology }\end{array}$ & Khodor et al., 2004 \\
\hline $\begin{array}{l}\text { Core ideas in } \\
\text { pathogen-host } \\
\text { interactions }\end{array}$ & 2007 & $\begin{array}{l}\text { Identified common anchor organisms and } \\
\text { six topic areas that would be integrated } \\
\text { across all courses in a series of courses }\end{array}$ & $\begin{array}{l}\text { Subdiscipline } \\
\text { undergraduate biology }\end{array}$ & Marbach-Ad et al., 2007 \\
\hline $\begin{array}{l}\text { Core ideas in } \\
\text { biochemistry }\end{array}$ & 2011 & $\begin{array}{l}\text { Used conceptual lens to demonstrate how } \\
\text { core ideas in biochemistry fit under } \\
\text { Vision and Change core concepts }\end{array}$ & $\begin{array}{l}\text { Subdiscipline } \\
\text { undergraduate biology }\end{array}$ & Rowland et al., 2011 \\
\hline Big ideas in physiology & 2009-2011 & $\begin{array}{l}\text { Unpacked five most important core } \\
\text { principles in physiology, including cell } \\
\text { membranes, homeostasis, cell-to-cell } \\
\text { communications, interdependence, and } \\
\text { flow-down gradients. }\end{array}$ & $\begin{array}{l}\text { Subdiscipline } \\
\text { undergraduate biology }\end{array}$ & $\begin{array}{l}\text { Michael et al., 2009; Michael } \\
\text { and McFarland, } 2011\end{array}$ \\
\hline Editorial & 2001 & $\begin{array}{l}\text { Evolution should be overarching } \\
\text { framework of biology }\end{array}$ & $\begin{array}{l}\text { General undergraduate } \\
\text { biology }\end{array}$ & Alles, 2001 \\
\hline Editorial & 2010 & $\begin{array}{l}\text { Three core conceptual foundations of } \\
\text { modern biology are evolutionary } \\
\text { thinking, molecular foundations, and } \\
\text { network behavior }\end{array}$ & $\begin{array}{l}\text { General undergraduate } \\
\text { biology }\end{array}$ & Klymkowsky, 2010 \\
\hline Editorial & 2010 & $\begin{array}{l}\text { Conceptual framework for biology that } \\
\text { includes five general theories: cells, } \\
\text { organisms, genetics, ecology, and } \\
\text { evolution }\end{array}$ & $\begin{array}{l}\text { General undergraduate } \\
\text { biology }\end{array}$ & Scheiner, 2010 \\
\hline $\begin{array}{l}\text { A framework for } \\
\text { Advanced Placement } \\
\text { Biology }\end{array}$ & 2002-2009 & $\begin{array}{l}\text { College Board's revision of the AP Biology } \\
\text { curriculum around four "big ideas" } \\
\text { and seven science practices }\end{array}$ & AP Biology & $\begin{array}{l}\text { Wood, } 2009 \\
\text { http://apcentral } \\
\text {.collegeboard.com/apc/ } \\
\text { public/courses/teachers } \\
\text { _corner/2117.html }\end{array}$ \\
\hline $\begin{array}{l}\text { A framework for } \mathrm{K}-12 \\
\text { science education }\end{array}$ & 2011 & $\begin{array}{l}\text { Crosscutting concepts that unify the study } \\
\text { of science; scientific and engineering } \\
\text { practices; and disciplinary core ideas }\end{array}$ & General K-12 biology & Quinn et al., 2011 \\
\hline $\begin{array}{l}\text { Vision and Change in } \\
\text { Undergraduate Biology } \\
\text { Education: A Call to } \\
\text { Action }\end{array}$ & 2011 & Identified five core concepts of biology & $\begin{array}{l}\text { General undergraduate } \\
\text { biology }\end{array}$ & AAAS, 2011 \\
\hline
\end{tabular}

which may explain why few have gained significant traction in the wider community. The most notable exception to this is the framework for K-12 education, which has recently been adopted as a set of scientific standards for elementary and secondary schools, but the focus of this set of recommendations is on $\mathrm{K}-12$ and not undergraduate biology.

At the undergraduate level, the most extensive effort has come from a collaboration between the National Science Foundation (NSF) and the American Association for the Advancement in Science (AAAS), which culminated in the report Vision and Change in Undergraduate Biology Education: A Call to Action (AAAS, 2011). Through a series of conversations at regional and national meetings, more than 500 biologists and biology educators discussed the need to reform undergraduate biology education and provided a set of unifying recommendations. Specifically, Vision and Change outlined five core concepts that are important for undergraduate biology majors to understand by the time they graduate (Table 2).

While it successfully distilled the complexity of biology down to only five core concepts, the recommendations set forth in Vision and Change were intentionally broad. They were meant to serve as "a resource and starting point" (AAAS, 2011, p. 11) for further delineation into subconcepts. The challenge is to elaborate the core concepts, so faculty members have a better grasp on how to teach them.

Taking the next step, the Society for Microbiology (Merkel, 2012), the American Society for Biochemistry and Molecular Biology (Tansey et al., 2013), and the American Society of Plant Biologists and Botanical Society of America (American Society of Plant Biologists, 2012) have outlined how the core

Table 2. Core concepts outlined in Vision and Change: A Call to Action (AAAS, 2011)

\section{Evolution}

2. Structure and function

3. Information flow, exchange, and storage

4. Pathways and transformations of energy and matter

5. Systems 
concepts of Vision and Change could be interpreted in each of their subdisciplines. While these society-specific efforts have been useful in making the core concepts more concrete for instructors teaching courses in these subdisciplines, their statements are often too specific for general biology majors, who are tasked with gaining a conceptual understanding of the discipline as a whole. To build on the important work coming out of the subdisciplines, we set out to interpret what the core concepts of Vision and Change mean for a general biology curriculum.

\section{TARGET AUDIENCE FOR BIOCORE GUIDE: GRADUATING GENERAL BIOLOGY MAJORS}

Although a unified curriculum for all undergraduate biology majors has not been established (Cheesman et al., 2007), there have been efforts focused on identifying both a common set of courses (Heppner et al., 1990; Marocco, 2000; National Research Council [NRC], 2003; Cheesman et al., 2007; Labov et al., 2010) and a common set of essential topics (Ledbetter and Campbell, 2005; Timmerman et al., 2008; AAAS, 2011; Gregory et al., 2011). However, in line with the increased specialization of biology, curricula have also been recommended for biochemistry (Voet et al., 2003), zoology (Russell, 2009), physiology (Silverthorn, 2003), and neuroscience (Wiertelak and Ramirez, 2008).

Would the biology community as a whole benefit more from recommendations for general biology majors or for subdiscipline-specific majors? To answer this question, we examined the structure of biology departments and majors at a randomly selected sample of 183 institutions throughout the United States (see Supplemental Material for methodology). As the data in Table 3 indicate, the vast majority of colleges and universities in our sample have general biology departments and confer a general biology degree. On the basis of these results, we concluded that the most useful approach for most institutions would be to articulate what the Vision and Change core concepts mean to faculty and students in a general biology program.

Table 3 Prevalence of general biology departments and general biology degrees ${ }^{\mathrm{a}}$

\begin{tabular}{lcc}
\hline $\begin{array}{c}\text { Institution type by } \\
\text { highest degree } \\
\text { granted }\end{array}$ & $\begin{array}{c}\text { Percentage of } \\
\text { institutions with a } \\
\text { general biology } \\
\text { department }\end{array}$ & $\begin{array}{c}\text { Percentage of } \\
\text { institutions that } \\
\text { confer a general } \\
\text { biology degree }\end{array}$ \\
\hline Bachelor & 74.1 & 96.3 \\
Master's & 87.5 & 95.8 \\
Doctorate & 90 & 93.3 \\
\hline
\end{tabular}

${ }^{a}$ Out of a random sample of $10 \%$ of the total number of Carnegieclassified institutions that confer bachelor's, master's, and doctoral degrees ( $n=183$ institutions), the majority has general biology departments and confer a general biology degree.

\section{CONCEPTUAL FRAMEWORK: CREATING THE BIOCORE GUIDE FOR VISION AND CHANGE'S CORE CONCEPTS}

With the core concepts of Vision and Change as a guide, we delineated a set of general principles for each concept. These principles are cross-disciplinary elaborations of each larger core concept intended to illustrate central themes that can be applied to different subdisciplines of biology. We also outlined a set of statements that were more specific interpretations of each of the core concepts within the three major subdisciplines of biology: molecular/cellular/developmental biology, physiology, and ecology/evolution. Although artificial-the three subdivisions do not exist as separate entities in organisms-they do represent the typical components of an introductory biology curriculum and span the scale of biology, from molecules to ecosystems. Thus, we used these subdisciplines as an attempt to sample the diversity of biology.

Collectively, we refer to the principles and statements as the Vision and Change BioCore Guide. Figure 1 summarizes the relationship between the different BioCore Guide elements and how the BioCore Guide itself relates to the broader goals of Vision and Change. We expect that the organization of core concepts, principles, and statements will be useful to the biology community as departments strive to adhere to the recommendations of Vision and Change. For example, test questions could be written that assess student understanding of each statement, and by extension, each principle and core concept.

\section{A GRASSROOTS APPROACH TO DEVELOPING THE VISION AND CHANGE BIOCORE GUIDE}

To develop a tool that biology faculty would use and endorse, we involved biology faculty at each step of the process. This bottom-up, grassroots approach differs from more traditional efforts that rely on small working groups, often composed of faculty members who are on education committees and/or engaged in education research, to investigate an issue, write a report summarizing their findings, and then disseminate these "best practices" to the broader academic community. Despite the popularity of these top-down methods, they have not been shown to be particularly effective for catalyzing faculty and institutional change (Henderson et al., 2010, 2011). Although we incorporated feedback from biology education researchers who have been policy makers at specific points in the development process, the goal of our "faculty-first" approach was to produce a tool that would resonate with instructors and thereby encourage implementation. An overview of our process is shown in Figure 2.

\section{Phase I. Home Institution Development and Review}

As a first step, we obtained input from biology faculty at the University of Washington. Specifically, we engaged faculty members with Vision and Change by having them consider whether the five core concepts of Vision and Change were important for graduating biology majors to understand. Using an online survey, we found strong alignment between the national goals of Vision and Change and faculty goals in this 


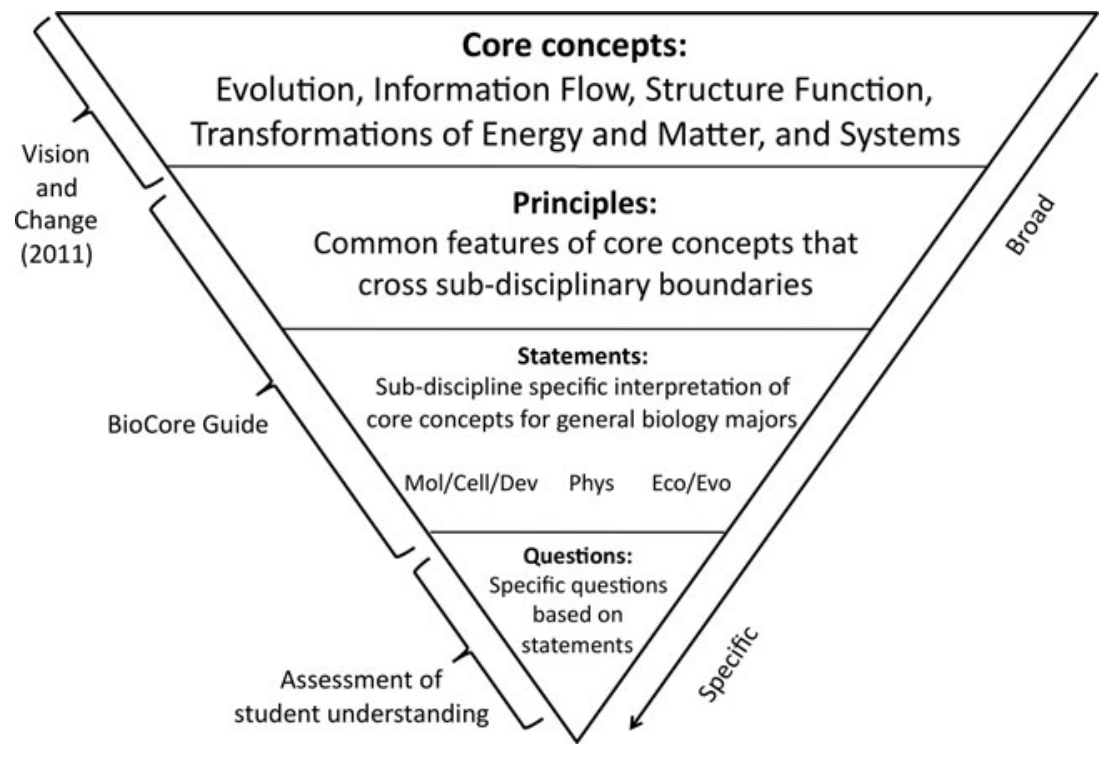

Figure 1. Conceptual framework for interpreting the core concepts of Vision and Change. Based on the core concepts of Vision and Change, the BioCore Guide consists of two levels: principles and statements. Specific questions based on the statements can be developed to assess student understanding of these concepts. department; all of the core concepts of Vision and Change were judged to be as important or more important than previously established departmental learning goals.

Our next step was to begin operationalizing the core concepts of Vision and Change into specific statements for each of the three major subdisciplines of biology. We did this by recruiting faculty to join one of three different focus groups with expertise in 1) molecular/cellular/developmental biology, 2) physiology, and 3) ecology/evolution. Faculty groups, each composed of three faculty members, independently brainstormed ideas for how each of the Vision and Change core concepts could be interpreted for their subdiscipline. They then refined their ideas to produce two to three statements for each of the core concepts, with each statement intended to capture features of their subdiscipline that they wanted general biology majors to master before graduation. We then assembled all the statements into a first-draft BioCore Guide. The "local" phase of the development process closed after three iterative revisions, based on discussions with the University of Washington (UW) Biology Education Research Group $(n=4)$, the Undergraduate Curriculum Committee $(n=11)$, and attendees at departmental faculty meetings $(n \sim 25)$.

\section{Phase II. National Review and Validation}

In the second phase of developing the BioCore Guide, we solicited feedback on the initial draft from biologists and biology educators with different subdiscipline expertise in biology at a diverse set of national institutions. Using a convenience-sampling approach, we identified biology faculty members who were content experts and asked them to evaluate each statement and provide feedback on: 1) its scientific accuracy/wording and 2) its importance in terms of what a general biology major should understand by the time he or she graduates. We encouraged respondents to provide written edits of each statement and also asked them to identify additional or missing concepts. Participants were reminded to focus on the level of understanding expected of a general biology major, not a specialist from one of the subdisci- plines. Twenty-five biologists (nine ecologists/evolutionary biologists, seven physiologists, and nine molecular/cellular biologists) provided written feedback. We then summarized their suggestions, identified consensus ideas, and modified the BioCore Guide accordingly. While we did not incorporate all of the suggestions, we did discuss each contribution and weighed its relevance in relationship to other suggestions.

Using the newly revised version of the BioCore Guide, we then solicited feedback from the biology education research community in two ways. We organized a focus group composed of five biology education researchers at the national meeting of the Society for Advancement in Biology Education (SABER) and asked participants to comment on the "big picture" organization of the document. This discussion resulted in two major changes to the BioCore Guide: 1) we developed broader principles under each concept, as a way to better organize the specific statements and see commonalities among subdisciplines; and 2) the biologically artificial boundaries among the subdisciplines were supplemented by a biologically relevant scale of molecules to ecosystems. In addition, we requested feedback on the BioCore Guide from professionals at SABER's national meeting whose work focused on instruction and discipline-based education research. Ten additional participants provided written comments on the accuracy of the statements and their importance for a graduating general biology major; these comments were used to further modify the BioCore Guide.

As a final step, we sought national validation of the BioCore Guide. We administered an anonymous online survey, distributed through mailing lists of a diverse group of scientific societies and education research groups (for a list of the organizations contacted, see the Supplemental Material). The voluntary survey asked reviewers to rate on a 4-point Likert scale ranging from "strongly disagree" to "strongly agree" whether each principle and statement in the BioCore Guide was 1) scientifically accurate and 2) important for a graduating biology major to understand. We intentionally did not provide reviewers will the option of a "neutral" response, because we wanted the reviewers to take a stance on each 


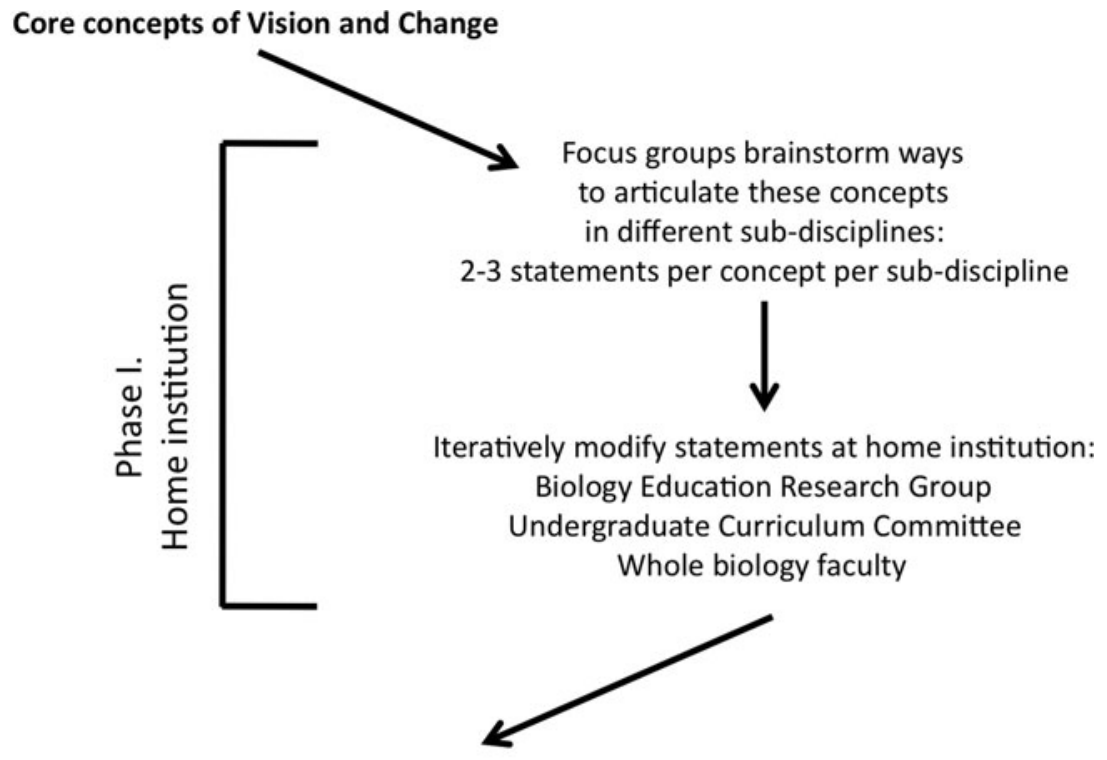

Iteratively modify statements nationally:

Biology content experts provide feedback

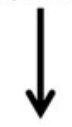

Iteratively modify statements nationally:

Biology education experts provide feedback
$\begin{gathered}\text { National validation of statements and principles } \\ \text { by biologists and biology educators }\end{gathered}$

Minor modifications to BioCore Guide

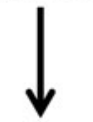

Final BioCore Guide is the product of feedback from 244 biologists and biology educators

Figure 2. The development process for the BioCore Guide. In this two-phase process, we began developing the BioCore Guide by soliciting input from faculty at the University of Washington. We then obtained feedback from biologists and biology educators nationally. In total, the BioCore Guide was iteratively revised six times. statement and felt that practicing biologists should be comfortable with all the topics required of a general biology major. Reviewers were also given the opportunity to provide specific edits or comments, including whether any major topics were missing from the BioCore Guide. We obtained feedback from 184 participants, who varied by subdiscipline expertise and type of institution (Table 4).

In sum, we collected individual written feedback from 244 biologists and biology educators. The comments and edits were extensive, indicating that respondents took the time to provide a thorough and thoughtful review of the BioCore Guide. The large number of written responses supports the claim that the BioCore Guide represents the most extensive and systematic collection of faculty opinion on the core concepts of Vision and Change to date.

\section{VISION AND CHANGE BIOCORE GUIDE OF CORE CONCEPTS FOR GENERAL BIOLOGY MAJORS}

Through our national validation, we received input on whether the principles and statements achieved scientific accuracy and whether they were important for a graduating general biology major to know. Table 5 summarizes the validation data for the five principles and 40 statements in the BioCore Guide by showing average percent agreement for each section.

More than $95 \%$ of respondents agreed that each of the principles was important for a general biology major to master before graduation (Table 5). In addition, more than $89 \%$ of respondents agreed with the scientific accuracy of each of the 
Table 4. Demographics of survey respondents for national validation $(n=184)$

\begin{tabular}{lr}
\hline Institution type & \\
Research university & $40.2 \%$ \\
Comprehensive university & $26.6 \%$ \\
Small liberal arts college & $19.0 \%$ \\
Community college & $11.4 \%$ \\
Other & $2.7 \%$ \\
Position & \\
Assistant/associate/full professor & $67.9 \%$ \\
Lecturer/instructor & $18.5 \%$ \\
Postdoctoral scholar & $4.3 \%$ \\
Graduate student & $3.3 \%$ \\
Other & $6.0 \%$ \\
Subdiscipline expertise & \\
Molecular/cellular/developmental biology & $41.85 \%$ \\
Physiology & $16.3 \%$ \\
Ecology/evolutionary biology & $41.85 \%$ \\
\hline
\end{tabular}

principles. Because reviewers had an opportunity to provide specific feedback on the principles, we were able to modify each principle to reflect the consensus feedback; the revised principles appear in Figure 3.

In the national validation of the statements, respondents agreed that all 40 of the statements were important for a graduating general biology major to know, with average agreement for each section being more than 93\% (Table 5). Reviewers also rated the scientific accuracy of the 40 statements highly; average agreement for scientific accuracy was more than $90 \%$ for each section. Reviewers suggested minor modifications to some statements. If at least three people in the national validation made the same suggestion, the alterations were incorporated into the BioCore Guide; the revisions are shown in Figure 3.
We gave reviewers the opportunity to recommend other concepts that may be important to include for a general biology major that we had not included on the BioCore Guide. No concepts were suggested by more than $5 \%$ of our sample, which we interpreted to mean that reviewers did not think that the BioCore Guide was missing any critically important statements. However, we do provide a list of these additional ideas in Supplemental Table S1, organized by core concept. Although these suggestions have not been validated, they could serve as a resource for biologists interested in incorporating a greater number of ideas into the BioCore Guide.

In addition to providing the version of the BioCore Guide that was sent for national validation, Supplemental Figure S1 indicates which principles and statements were modified to produce Figure 3 and reports the averages on the Likert scale of $1-4$ ( $1=$ strongly disagree; $4=$ strongly agree $)$ and percentages of agreement for importance and scientific accuracy for each statement and principle based on the national survey.

The final Vision and Change BioCore Guide of core concepts, shown in Figure 3, has been built by 244 members of the biology community and iteratively revised a total of six times. For each core concept, the BioCore Guide consists of a set of cross-disciplinary principles and two to three statements for each subdiscipline.

\section{WHERE DO THE CORE COMPETENCIES OF VISION AND CHANGE FIT IN?}

Vision and Change outlined a set of core competencies in addition to the five core concepts. These include the ability to: 1) apply the process of science, 2) use quantitative reasoning, 3) use modeling and simulation, 4) tap into the interdisciplinary nature of science, 5) communicate and collaborate with other disciplines, and 6) understand the relationship between science and society. We chose to focus on explicating the core concepts of biology rather than the core

Table 5. Percentage of national agreement with BioCore Guide principles and statements ${ }^{\mathrm{a}}$

\begin{tabular}{|c|c|c|c|c|c|}
\hline & \multicolumn{2}{|c|}{ Principles } & & \multicolumn{2}{|c|}{ Statements } \\
\hline & $\begin{array}{l}\text { Scientific } \\
\text { accuracy }\end{array}$ & $\begin{array}{l}\text { Important for } \\
\text { graduating biology } \\
\text { major to know }\end{array}$ & & $\begin{array}{l}\text { Scientific } \\
\text { accuracy }\end{array}$ & $\begin{array}{l}\text { Important for } \\
\text { graduating biology } \\
\text { major to know }\end{array}$ \\
\hline Evolution & $96 \%$ & $98 \%$ & $\begin{array}{l}\text { Mol/Cell } \\
\text { Phys } \\
\text { Eco/Evo }\end{array}$ & $\begin{array}{l}96 \% \\
91 \% \\
95 \%\end{array}$ & $\begin{array}{l}99 \% \\
95 \% \\
97 \%\end{array}$ \\
\hline Information flow & $97 \%$ & $99 \%$ & $\begin{array}{l}\text { Mol/Cell } \\
\text { Phys } \\
\text { Eco/Evo }\end{array}$ & $\begin{array}{l}98 \% \\
98 \% \\
98 \%\end{array}$ & $\begin{array}{l}97 \% \\
97 \% \\
99 \%\end{array}$ \\
\hline Structure function & $91 \%$ & $97 \%$ & $\begin{array}{l}\text { Mol/Cell } \\
\text { Phys } \\
\text { Eco/Evo }\end{array}$ & $\begin{array}{l}97 \% \\
96 \% \\
95 \%\end{array}$ & $\begin{array}{l}96 \% \\
93 \% \\
94 \%\end{array}$ \\
\hline $\begin{array}{l}\text { Transformations of } \\
\text { energy and matter }\end{array}$ & $89 \%$ & $95 \%$ & $\begin{array}{l}\text { Mol/Cell } \\
\text { Phys } \\
\text { Eco/Evo }\end{array}$ & $\begin{array}{l}99 \% \\
98 \% \\
97 \%\end{array}$ & $\begin{array}{l}96 \% \\
94 \% \\
95 \%\end{array}$ \\
\hline Systems & $94 \%$ & $97 \%$ & $\begin{array}{l}\text { Mol/Cell } \\
\text { Phys } \\
\text { Eco/Evo }\end{array}$ & $\begin{array}{l}99 \% \\
98 \% \\
95 \%\end{array}$ & $\begin{array}{l}93 \% \\
95 \% \\
96 \%\end{array}$ \\
\hline
\end{tabular}

${ }^{\text {a } D a t a ~ s h o w n ~ a r e ~ a v e r a g e ~ p e r c e n t a g e ~ a g r e e m e n t ~ f o r ~ e a c h ~ p r i n c i p l e ~ a n d ~ f o r ~ a l l ~ t h e ~ s t a t e m e n t s ~ f o r ~ e a c h ~ s u b d i s c i p l i n e ~ f r o m ~} 184$ respondents. 


\begin{tabular}{|c|c|c|}
\hline \multicolumn{3}{|c|}{ Major Subdisciplines of Biology } \\
\hline $\begin{array}{c}\text { Molecular/ Cellular/ } \\
\text { Developmental } \\
\text { Biology }\end{array}$ & Physiology & $\begin{array}{c}\text { Ecology/ } \\
\text { Evolutionary } \\
\text { Biology }\end{array}$ \\
\hline
\end{tabular}

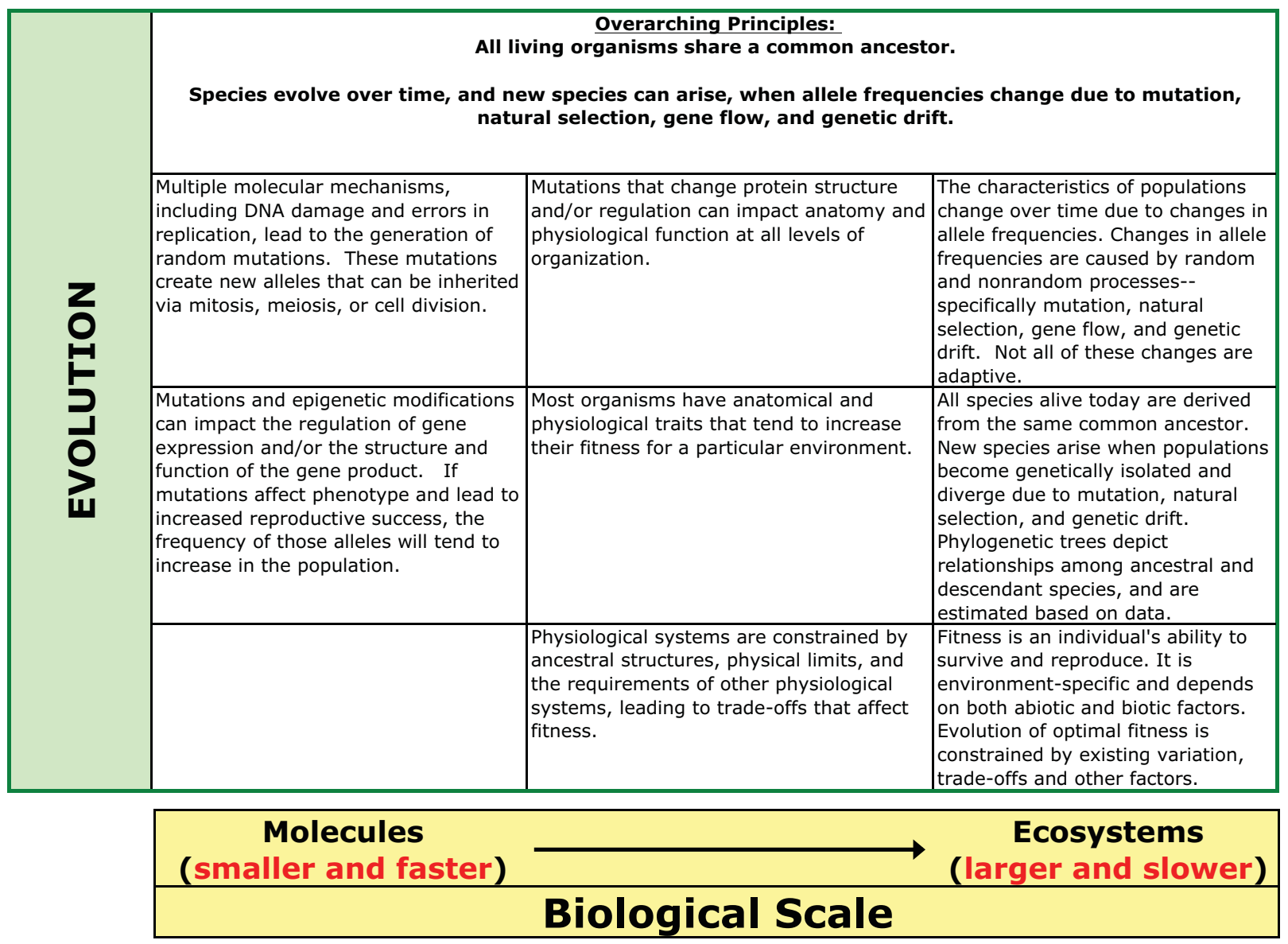

Figure 3. BioCore Guide: a nationally validated tool for interpreting the core concepts of Vision and Change. We present the principles and statements that encompass the BioCore Guide, which have been built by more than 200 people in the biology community. The columns represent the three major subdisciplines of biology (molecular/cellular/developmental biology, physiology, and ecology/evolutionary biology), which are also depicted on a biological scale from the molecular to the ecosystem level. Each concept is represented by a separate box, with a set of overarching principles that cross subdisciplinary boundaries at the top and then two to three statements for each of the subdisciplines. (Continued on next page)

competencies, simply because we found the concepts to be more controversial with faculty-we observed much lower consensus among faculty members regarding what the five core concepts mean for their subdiscipline. Although this essay focuses solely on the core concepts, it is not because the competencies are less important. In our view, it is essential to address both core concepts and competencies as we work toward undergraduate biology reform.

\section{THE BIOCORE GUIDE SPANS A 4-YR UNDERGRADUATE BIOLOGY CURRICULUM}

Although many of the BioCore Guide statements are addressed in introductory biology courses because of their fundamental importance, some may be more appropriately taught in advanced courses. We did not determine at what level each statement should be taught, but emphasize that the BioCore Guide is intended to be used beyond introductory biology. We strongly encourage its use across the curriculum in ways that will promote an emphasis on the core concepts-even in upper-level courses with highly specialized topics. We hope that the BioCore Guide will promote dialogue about when each of these statements should be taught and how basic concepts can be elaborated on and reinforced in upper-level courses. Students need multiple opportunities to work with an idea to help them understand it at a deeper level. Additionally, engaging with the same concepts across the curriculum will help students understand the importance of using these core concepts as a way to structure their thinking about biology. 


\begin{tabular}{|c|c|c|c|}
\hline & \multicolumn{3}{|c|}{$\begin{array}{l}\text { Overarching Principles: } \\
\text { Organisms inherit genetic and epigenetic information that influences the location, timing, and intensity of } \\
\text { gene expression. }\end{array}$} \\
\hline & $\begin{array}{l}\text { In most cases, genetic information } \\
\text { flows from DNA to mRNA to protein, } \\
\text { but there are important exceptions. }\end{array}$ & $\begin{array}{l}\text { Information stored in DNA is expressed as } \\
\text { RNA and proteins. These gene products } \\
\text { impact anatomical structures and } \\
\text { physiological function. }\end{array}$ & $\begin{array}{l}\text { Individuals transmit genetic } \\
\text { information to their offspring; some } \\
\text { alleles confer higher fitness than } \\
\text { others in a particular environment. }\end{array}$ \\
\hline$\frac{1}{2}$ & $\begin{array}{l}\text { Gene expression and protein activity } \\
\text { are regulated by intracellular and } \\
\text { extracellular signaling molecules. } \\
\text { Signal transduction pathways are } \\
\text { crucial in relaying these signals. }\end{array}$ & $\begin{array}{l}\text { Organisms have sophisticated mechanisms } \\
\text { for sensing changes in the internal or } \\
\text { external environment. They use chemical, } \\
\text { electrical, or other forms of signaling to } \\
\text { coordinate responses at the cellular, } \\
\text { tissue, organ, and/or system level. }\end{array}$ & $\begin{array}{l}\text { A genotype influences the range of } \\
\text { possible phenotypes in an } \\
\text { individual; the actual phenotype } \\
\text { results from interactions between } \\
\text { alleles and the environment. }\end{array}$ \\
\hline$z$ & $\begin{array}{l}\text { The signals that a cell receives depend } \\
\text { on its location, and may change } \\
\text { through time. As a result, different } \\
\text { types of cells express different genes, } \\
\text { even though they contain the same } \\
\text { DNA. }\end{array}$ & & \\
\hline
\end{tabular}

\begin{tabular}{|c|c|c|c|}
\hline & \multicolumn{3}{|c|}{$\begin{array}{l}\text { Overarching Principles: } \\
\text { Biological structures exist at all levels of organization, from molecules to ecosystems. A structure's } \\
\text { physical and chemical characteristics influence its interactions with other structures, and therefore its } \\
\text { function. } \\
\text { Natural selection leads to the evolution of structures that tend to increase fitness } \\
\text { within the context of evolutionary, developmental, and environmental constraints. }\end{array}$} \\
\hline & $\begin{array}{l}\text { The structure of a cell--its shape, } \\
\text { membrane, organelles, cytoskeleton, } \\
\text { and polarity--impacts its function. }\end{array}$ & $\begin{array}{l}\text { Physiological functions are often } \\
\text { compartmentalized into different cells, } \\
\text { tissues, organs, and systems, which have } \\
\text { structures that support specialized } \\
\text { activities. }\end{array}$ & $\begin{array}{l}\text { Natural selection has favored } \\
\text { structures whose shape and } \\
\text { composition contribute to their } \\
\text { ecological function. }\end{array}$ \\
\hline & $\begin{array}{l}\text { The three dimensional structure of a } \\
\text { molecule and its subcellular localization } \\
\text { impact its function, including the ability } \\
\text { to catalyze reactions or interact with } \\
\text { other molecules. Function can be } \\
\text { regulated through reversible alterations } \\
\text { of structure e.g. phosphorylation. }\end{array}$ & $\begin{array}{l}\text { The size, shape, and physical properties of } \\
\text { organs and organisms all affect function. } \\
\text { The ratio of surface area to volume is } \\
\text { particularly critical for structures that } \\
\text { function in transport or exchange of } \\
\text { materials and heat. }\end{array}$ & $\begin{array}{l}\text { Competition, mutualism, and other } \\
\text { interactions are mediated by each } \\
\text { species' morphological, } \\
\text { physiological, and behavioral traits. }\end{array}$ \\
\hline & $\begin{array}{l}\text { The structure of molecules or } \\
\text { organisms may be similar due to } \\
\text { common ancestry or selection for } \\
\text { similar function. }\end{array}$ & $\begin{array}{l}\text { Structure constrains function in } \\
\text { physiology; specialization for one function } \\
\text { may limit a structure's ability to perform } \\
\text { another function. }\end{array}$ & \\
\hline & $\begin{array}{c}\text { Molecules } \\
\text { (smaller and faster) }\end{array}$ & & $\begin{array}{c}\text { Ecosystems } \\
\text { (larger and slower) }\end{array}$ \\
\hline
\end{tabular}

Figure 3. (Continued)

Outlining how topics could be taught across the curriculum could help us develop learning progressions for these concepts in undergraduate biology (Duncan and Rivet, 2013). It may be important to reinforce statements that are introduced early in an undergraduate's career-restating and reminding, but perhaps also elaborating. An increasingly sophisticated understanding might focus on the complexity of biological in- teractions and processes, helping students move from thinking about single molecules, signal transduction pathways, or communities to analyzing the complex interactions that exist among these different entities. Further, while general or canonical examples might be presented in introductory courses, upper-level classes could explore important exceptions, delve into the primary literature, or challenge students 


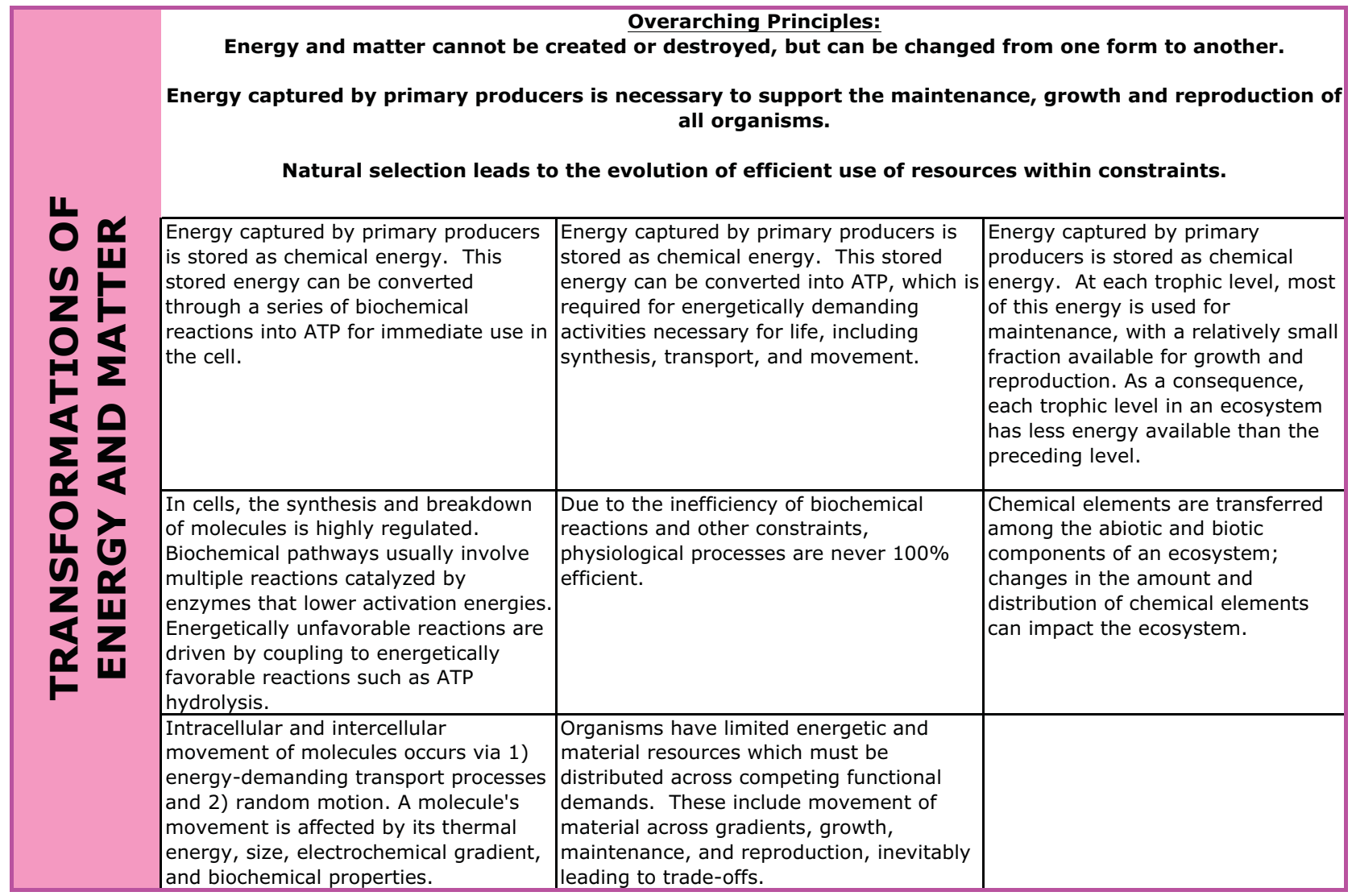

\section{Overarching Principles:}

Biological molecules, genes, cells, tissues, organs, individuals, and ecosystems interact to form complex networks. A change in one component of the network can affect many other components.

Organisms have complex systems that integrate internal and external information, incorporate feedback control, and allow them to respond to changes in the environment.

\begin{tabular}{|l|l}
\hline Cells receive a complex array of & Organ systems are not isolated, but
\end{tabular} chemical and physical signals that vary interact with each other through chemical in time, location, and intensity over the and physical signals at the level of cells, lifespan of the organism; a cell's response depends on integration and coordination of these various signals.

During development, the signals a cell receives depend on its spatial orientation within the embryo and its intercellular interactions. As a consequence, cells adopt different cell fates depending on their local environment and/or cell lineage.

Alteration of a single gene or molecule in a signaling network may have complex impacts at the cell, tissue or whole-organism level.

In the face of environmental changes, organisms may maintain homeostasis through control mechanisms that often use negative feedback; others have tissues, and organs.

An individual's physiological traits affect its Ecosystems are not isolated and interactions with other organisms and with static--they respond to change, its physical environment. abiotic factors.
The size and structure of populations are dynamic. A species' abundance and distribution is limited by available resources and by interactions between biotic and

both as a result of intrinsic changes to networks of species and as a result of extrinsic environmental drivers. Within an ecosystem, interactions among individuals form networks; changes in one node of a network can cause changes in other nodes--directly or indirectly. adaptations that allow them to acclimate to environmental variation.
Biodiversity impacts many aspects of ecosystems.

\begin{tabular}{|ccc|}
\hline \multirow{2}{*}{$\begin{array}{c}\text { Molecules } \\
\text { (smaller and faster) }\end{array}$} & $\begin{array}{c}\text { Ecosystems } \\
\text { (larger and slower) }\end{array}$ \\
\cline { 2 - 2 } & Biological Scale \\
\hline
\end{tabular}


to engage more with the Vision and Change core competencies.

Consider a BioCore Guide statement from the information flow concept under molecular/cellular biology: "In most cases, genetic information flows from DNA to mRNA to protein, but there are important exceptions." We imagine that most introductory courses cover the basic ideas of transcription and translation but may not address the exceptions to the DNA $\rightarrow$ mRNA $\rightarrow$ protein pathway or how the flow of genetic information is controlled. In upper-level molecular biology courses, more of the details and exceptions will likely be introduced. For example, students may be asked to explore the role of microRNAs in gene regulation or to analyze examples of successive reduction in genome size in somatic cells during development in organisms such as Tetrahymena or lamprey. Finally, upper-level courses may have students read primary literature or interpret data that either support or refute a given statement related to this core idea.

\section{USING THE BIOCORE GUIDE TO IMPROVE THE UNDERGRADUATE CURRICULUM}

We envision at least five major purposes for this BioCore Guide, which we outline below.

\section{Strengthening Connections between Course-Specific Learning Goals and the Core Concepts from Vision and Change}

There are few guidelines for faculty to use when developing course goals and learning outcomes. The BioCore Guide furnishes a nationally validated guideline for identifying student learning objectives and other course outcomes. If a faculty member aligns course goals with statements from the BioCore Guide, that instructor, along with other faculty teaching in the department, should gain a better understanding of how specific course activities can help students reach nationally validated goals for biology majors. In addition, students may be able to see which courses target the same statements and better appreciate common themes among courses or how course sequences build on each other.

\section{Aligning a Curriculum with the BioCore Guide to Identify Gaps}

Most departments strive to offer a cohesive curriculum for general biology majors. But currently, faculty members who teach upper-level courses are often unaware of what their colleagues are teaching in introductory courses. If so, courses and curricula can become disconnected from one another. Identifying which concepts are addressed in which coursesby mapping a suite of required courses onto the BioCore Guide-could allow departments to identify gaps in their curriculum (e.g., statements not targeted by any courses) and assess whether prerequisite courses introduce the core concepts that upper-level courses build upon.

\section{Help Undergraduates See the "Big Picture" of Biology} Undergraduate majors frequently wrestle with how the details they are learning in various courses fit into a larger, syn- thetic view of biology. Faculty advisors could use the BioCore Guide to help students see how their required biology and non-biology courses fit together and how courses with differences in subject matter (e.g., ecology and molecular biology) have common underlying principles.

\section{Accreditation and Certification}

Department chairs, committee heads, and deans could use the BioCore Guide during the accreditation process to articulate larger curricular goals. In addition, work has begun on developing a certification program for departments that align their programs with the goals of Vision and Change. The Partnership for Undergraduate Life Sciences Education (PULSE) is a collaborative effort developed and funded by the National Institute of General Medical Sciences of the National Institutes of Health and the Howard Hughes Medical Institute to catalyze the adoption of the goals outlined in the Vision and Change report. The PULSE organization has started the process by creating rubrics for departments to use in assessing alignment (PULSE Community, 2014). The BioCore Guide could be used in conjunction with the PULSE rubrics as a way for departments to self-assess their current status at meeting curricular learning outcomes aligned with the core concepts.

\section{Use the BioCore Guide as a Basis for Diagnostic Programmatic Assessments}

The biology community is largely in agreement that undergraduate biology majors should master the core concepts outlined in Vision and Change by the time they graduate. We now need a way of assessing whether they have achieved that understanding. There are a number of different approaches for testing student understanding of fundamental concepts (e.g., Nehm and Schonfeld, 2008; Shi et al., 2010; Hartley et al., 2011; Smith et al., 2013), each with its own strengths. However, the community currently lacks a test that could be easily administered to thousands of students to serve the needs of biology departments interested in assessing general biology majors' understanding of the core concepts spanning the subdisciplines.

Thus, as part of a multi-institution team (University of Washington, University of Maine, University of Colorado-Boulder, Arizona State University, and University of Nebraska-Lincoln), we are using this BioCore Guide to develop a restricted-response programmatic assessment that will track undergraduate biology majors' understanding of core concepts as they progress through the major. As our goal is to produce a test that could be used at the departmental or programmatic level—not the individual course level—we are proposing that it be administered to students at multiple time points in a curriculum: 1) before introductory biology, to assess students' incoming knowledge; 2) after completion of an introductory biology series, to gauge students' intermediate progress; and 3) before graduation, to determine the summative impact of the biology curriculum. Collecting baseline scores for students will allow institutions that have students transferring in at different points in the curriculum or students entering with different abilities to see the specific impact of their program on student understanding of the core concepts. We are intentionally structuring questions 
to target both introductory and advanced levels of thinking so that we can monitor improvement of student thinking as students progress through the curriculum. Success with the advanced-level questions would require higher-order cognitive understanding of one topic and/or across-discipline thinking that requires students to think broadly about biological concepts. Taking an integrative approach, focused on assessing student learning of diverse topics in biology at multiple stages of a general biology curriculum, will make this test distinct from previously developed concept inventories, capstone assessments, and subdiscipline-specific efforts. We are currently developing questions for this diagnostic tool, each of which will be aligned with the BioCore Guide, and thus Vision and Change, with the goal of producing a general biology test that would be available to interested institutions in the next few years. Departments could then use this programmatic assessment to monitor student learning and make evidence-based revisions to their curricula.

\section{ADAPTING THE BIOCORE GUIDE FOR USE AT YOUR OWN INSTITUTION}

We offer this BioCore Guide as a starting point for the five applications listed above and acknowledge that the goals of undergraduate biology education will evolve as the field of biology changes. Thus, the framework is not intended to be static; it will need to be modified and updated over time.

Departments may even wish to adapt this BioCore Guide immediately, so that it conforms more closely to their interests, needs, and departmental culture. Although a departmentally modified BioCore Guide will not have national validation, it may be more effective in terms of promoting faculty acceptance and institutional change.

In addition, the BioCore Guide is not meant to be prescriptive. The statements should not be viewed as a checklist for faculty instruction or be used to constrain what biology faculty teaches. Much of what excites us and our students lies in the details of our fields: a rare genetic disease, the crystal structure of a $G$ protein-coupled receptor, the impact of climate change on salamander populations, the relationship between stress and Alzheimer's disease. Far from pushing faculty away from a personalized view of biology, our goal is to give instructors an organizing framework to position specific examples, moving the focus away from a collection of facts and toward a more cohesive picture of our science.

This BioCore Guide, implemented in conjunction with the PULSE community's rubrics and ultimately with our programmatic assessment, could help departments incorporate the Vision and Change call to action into their institutional culture. We envision this BioCore Guide as an agent of change to help us complete this journey.

\section{ACKNOWLEDGMENTS}

This work was funded in part by the University of Washington College of Arts and Sciences, the University of Washington Department of Biology, and NSF DUE 1323010 collaborative research grant: University of Washington: P.I. A.J.C., S.F.; Arizona State University: Co-P.I. S.E.B.; University of Maine: P.I. M. Smith; University of Colorado-Boulder: PI J. Knight, Co-P.I. B. Couch. We thank the UW faculty who participated in this effort, particularly Toby Bradshaw and Kevin Mihata for leadership. We also thank members of the Biol- ogy Education Research Group, in particular Mercedes Converse for her help. Finally we thank the 50-plus people who provided specific feedback on the BioCore Guide (see the Supplemental Material for full list of names) and the 184 respondents who anonymously completed the national validation of the BioCore Guide, greatly strengthening the quality of this work.

\section{REFERENCES}

Alles DL (2001). Using evolution as the framework for teaching biology. Am Biol Teach 63, 20-23.

American Association for the Advancement of Science (2011). Vision and Change in Undergraduate Biology Education: A Call to Action, Washington, DC.

American Society of Plant Biologists (2012). Core Concepts and Learning Objectives. http://my.aspb.org/blogpost/722549/ 152613/Core-Concepts-and-Learning-Objectives-in-Undergraduate -Plant-Biology (accessed 20 December 2013).

Cheesman K, French D, Cheesman I, Swails N, Thomas J (2007). Is there any common curriculum for undergraduate biology majors in the 21st century? BioScience 57, 516-522.

Duncan RG, Rivet AE (2013). Science learning progressions. Science 339, 396-397.

Gregory E, Ellis JP, Orenstein AN (2011). A proposal for a common minimal topic set in introductory biology courses for majors. Am Biol Teach 73, 16-21.

Hartley LM, Wilke BJ, Schramm JW, D'Avanzo C, Anderson CW (2011). College students' understanding of the carbon cycle: contrasting principle-based and informal reasoning. BioScience 61, 65-75.

Henderson C, Beach A, Finkelstein N (2011). Facilitating change in undergraduate STEM instructional practices: an analytic review of the literature. J Res Sci Teach 48, 952-984.

Henderson C, Finkelstein N, Beach A (2010). Beyond dissemination in college science teaching: an introduction to four core change strategies. J Coll Sci Teach 39(5), 18-25.

Heppner F, Hammen C, Kass-Simon G, Krueger W (1990). A de facto standardized curriculum for US college biology and zoology. BioScience 40, 130-134.

Khodor J, Halme DG, Walker GC (2004). A hierarchical biology concept framework: a tool for course design. Cell Biol Educ 3, 111-121.

Klymkowsky MW (2010). Thinking about the conceptual foundations of the biological sciences. CBE Life Sci Educ 9, 405-407.

Labov JB, Reid AH, Yamamoto KR (2010). Integrated biology and undergraduate science education: a new biology education for the twenty-first century? CBE Life Sci Educ 9, 10-16.

Ledbetter ML, Campbell AM (2005). A survey of survey courses: are they effective? Argument favoring a survey as the first course for majors. Cell Biol Educ 4, 133-137.

Marbach-Ad G et al. (2007). A faculty team works to create content linkages among various courses to increase meaningful learning of targeted concepts of microbiology. CBE Life Sci Educ 6, 155-162.

Marocco DA (2000). Biology for the 21st century: the search for a core. Am Biol Teach 62, 565-569.

Merkel S (2012). The development of curricular guidelines for introductory microbiology that focus on understanding. J Microbiol Biol Educ 13, 32.

Michael J, McFarland J (2011). The core principles ("big ideas") of physiology: results of faculty surveys. Adv Physiol Educ 35, 336341.

Michael J, Modell H, McFarland J, Cliff W (2009). The "core principles" of physiology: what should students understand? Adv Physiol Educ 33, 10-16. 
National Research Council (2003). BIO2010, Transforming Undergraduate Education for Future Research Biologists, Washington, DC: National Academies Press.

Nehm R, Schonfeld IS (2008). Measuring knowledge of natural selection: a comparison of the CINS, an open-response instrument, and an oral interview. J Res Sci Teach 45, 1131-1160.

PULSE Community (2014). Home page. www.pulsecommunity.org (accessed 4 February 2014).

Quinn H, Schweingruber H, Keller T (eds.) (2011). A Framework for K-12 Science Education: Practices, Crosscutting Concepts, and Core Ideas, Washington, DC: National Academies Press.

Rowland DL, Smith CA, Gillam EM, Wright T (2011). The concept lens diagram: a new mechanism for presenting biochemistry content in terms of "big ideas." Biochem Mol Biol Educ 39, 267-279.

Russell AP (2009). Situating and teaching 21st century zoology: revealing pattern in the form and function of animals. Integr Zool 4, 309-315.

Scheiner SM (2010). Toward a conceptual framework for biology. Q Rev Biol 85, 293-318.

Shi J, Wood WB, Martin JM, Guild NA, Vicens Q, Knight JK (2010). Diagnostic assessment for introductory molecular and cell biology. CBE Life Sci Educ 9, 453-461.
Silverthorn DU (2003). Restoring physiology to the undergraduate biology curriculum: a call for action. Adv Physiol Educ 27, 9196.

Smith JI et al. (2013). Development of the biology card sorting task to measure conceptual expertise in biology. CBE Life Sci Educ 12, 628-644.

Tansey JT, Baird T, Cox MM, Fox KM, Knight J, Sears D, Bell E (2013). Foundational concepts and underlying theories for majors in "biochemistry and molecular biology." Biochem Mol Biol Educ 41, 289-296.

Timmerman BE, Strickland DC, Carstensen SM (2008). Curricular reform and inquiry teaching in biology: where are our efforts most fruitfully invested? Integr Comp Biol 48, 226240.

Voet JG, Bell E, Boyer R, Boyle J, O’Leary M, Zimmerman JK (2003). Recommended curriculum for a program in biochemistry and molecular biology. Biochem Mol Biol Educ 31, 161-162.

Wiertelak EP, Ramirez JJ (2008). Undergraduate neuroscience education: blueprints for the 21st century. J Undergrad Neurosci Educ 6, A34-A39.

Wood WB (2009). Revising the AP biology curriculum. Science 325, $1627-1628$. 